\title{
ISMOP Project (IT System of Levee Monitoring) as an example of integrated monitoring of levee
}

\author{
Jacek Stanisz, Klaudia Korzec, Aleksandra Borecka \\ AGH University of Science and Technology, Faculty of Geology, Geophysics and Environmental Protection; al. Mickiewicza 30, \\ 30-059 Krakow,Poland; e-mail: jstanisz@agh.edu.pl,kkorzec@agh.edu.pl, aborecka@agh.edu.pl
}

(C) 2015 Authors. This is an open access publication, which can be used, distributed and reproduced in any medium according to the Creative Commons CC-BY 4.0 License requiring that the original work has been properly cited.

The technical condition of levees is decides on the safety of property and persons residing in the protected areas. Monitoring is an important issue.

Levees in Poland have been used, in the majority, for over 20 (22\% of embankments) or 40 (59\% of embankments) years. They were formed from accidental, heterogeneous material and they are characterized by their uneven compaction (Borys 2007).

The European experiences indicate the use of many technical solutions in the scope of levee monitoring. Two approaches can be differentiated: a local approach - concerning the levee condition and a global approach - comprising the issues of water management and flood safety. The global approach was implemented in Imprints, WeSenseIt, and the most advanced - UrbanFlood projects. In Poland, such an approach is implemented by the National Water Management Authority (KZGW) within the framework of the IT System of the Country's Protection (ISOK) project. The local approach was adopted in the projects of the French Cemagref (today's Irstea), IJkdijk, DredgDikes or the Polish ISMOP (Zhu et al. 2009, Cunat et al. 2010, Khan et al. 2010, Artières et al. 2011, Courivaud et al. 2011, Pięta et al. 2014, Stanisz et al. 2014).

There has been little research concerning the behaviour of levee in Poland. Currently, with the cooperation of AGH University of Science and Technology in Kraków and the following companies: SWECO Hydroprojekt Kraków sp. z o.o., Neosentio and ZPPUH Budokop Sp. z o.o, a project titled, IT System of Levee Monitoring (ISMOP), is being conducted. A system approach to the issue of flood earth embankment monitoring is the aim of the Project. The purpose of the research is the creation of a system which monitors the static and dynamic behaviour of levee in real time. ISMOP is aimed at the mass gathering of data concerning selected processes taking place in the levee, optimization of data transfer as well as the interpretation and analysis, with the use of numerical simulations and a system of visualization, of the levee's condition.

The use of a number of sensors monitoring changes within the body and their comparison with the results of numerical simulations is an innovation (linked mechanical, hydrological and thermal models) (Bukowska-Belniak \& Krawiec 2014). The proposed approach enables a prediction of the levee condition, with a defined probability of the occurrence of processes having unfavourable impact on the levee structure, to be made (Piórkowski \& Leśniak 2014).

An experimental levee at a scale of 1:1 (width $\times$ length $\times$ height $=58 \times 208 \times 4.5 \mathrm{~m}$ ) was built within the framework of the project. It consists of two, parallel sections formed of soils with a variable filtration coefficient. The research is taking place in Czernichów, 20 km west of Kraków.

Sensors in three measurement profiles were placed in the levee. Monitoring inside the embankment comprises a local measurement of pore pressure ( $35 \mathrm{pcs})$, temperature ( $35 \mathrm{pcs})$ and soil pressure (6 pcs). In addition, 6 inclinometers 
(length $-6.5 \mathrm{~m}$ each) and 24 piezometres (total length $82 \mathrm{~m}$ ) were included in the construction. Linear measurement of the temperature with the use of a sensory optoelectronic cable (ca. $1300 \mathrm{~m}$ ) is also being conducted. In the vicinity of the levee a weather station was located in order to monitor weather conditions. Measurements delivered by the network of sensors during experiments constitute the major element of tightness assessment and, indirectly, the levee stability assessment.

In addition, the levee surface monitoring, based on survey methods - classical measurements (tacheometers, GPS) and with the use of aboveground long-range interferometric radar, is being performed (IBIS-L). Within the duration of the experiment, an infra-red camera FLIR T620 was used. Geophysical measurements, using the electrical resistance method, are carried out on external parts of the designed levee.

The use of optoelectronic technology is an important aspect. The project enables verification of its efficiency within the duration of an artificially evoked freshet wave. The measurement scenarios performed assume repeated high water levels depending on the simulation of the wave flowing through the watershed of mountainous, upland or lowland environments.

Physical and mechanical parameters measured by sensors are recorded and analysed on an Automatic Measurement System. On the basis of data coming from the sensors and numerical models the system performs a risk assessment in real time. Based on the analysis of the group of measured parameters, an alarm signal, indicating a crisis situation, is activated in a hazard situation.

This fact will be reported in the following cases:

- the increase in the parameter value within a defined time period,

- changes of admissible gradients,

- exceeding more than one alarm level,

- damage of apparatus or communication errors (anomalous readouts or the lack of readouts).

The occurrence of risk in a given flood situation will result in the activation of the procedure increasing the frequency of sampling of measured physical values. At the moment of lowering the water table, the sampling step will be decreased. Such a solution will enable less power consumption and will automatically shift into "stand-by" mode allowing for, e.g., system maintenance or sensor calibration.

The ISMOP project will also ensure the verification of data obtained from the measurements by the optoelectronic method and other measurement sensors by numerical models. Preliminary results of numerical simulations indicate the places where the levee's stability is lost, and the course of the filtration curve. Within their duration, the linear relationship between changes in temperature and pore pressure in the levee body, with a low hydraulic gradient, has been demonstrated. In the case of increased flow, the increase in pore pressure value is higher than the increase in temperature value.

Tests will determine the measurement methodology and they will also verify the substantiation of the installation of particular sensors in flood embankments. Close cooperation between scientists and designers may contribute to the determination of new, economically substantiated, standards of embankment condition assessment both during and after a flood.

The project is financed under grant No. PBS1/ B9/18/2013 awarded by the National Centre for Research and Development within the framework of the Applied Research Programme.

\section{REFERENCES}

Artières O., Beck Y.L., Khan A.A., Cunat P. Fry J.J., Courivaud J.R., Guidoux C. \& Pinettes P., 2011. Assessment of dams and dikes behavior with a fibre optics based monitoring solution. Dam Maintenance \& Rehabilitation II, Taylor \& Francis Group, London, 79-86.

Borys M., 2007. Przepisy i wymogi oraz aktualny stan obwałowań przeciwpowodziowych w Polsce. Woda - Środowisko - Obszary Wiejskie, 7, 2a, 25-44.

Bukowska-Belniak B. \& Krawiec K., 2014. Influence of the shape and density of grid computing to the accuracy of the numerical simulation results of the flood embankments mode. 14th Geoconference on Informatics, Geoinformatics and Remote Sensing, Conference proceedings, 1, 648-649.

Courivaud J-R., Pinettes P., Guidoux C., Fry J.J. \& Beck Y.L., 2011. Fiber optics based monitoring of levees and embankment dams. 31st Annual USSD Conference, 1561-1577.

Cunat P., Beck Y.L., Faure Y.H. \& Fry J.J., 2010. Aplication of thermometric methods for detection and characterization of leakages in embankment dams. CDA 2010 Annual Conference, $1-7$. 
Khan A.A., Cunat P., Beck Y.L. Mars J.I., Vrabie V. \& Fabre J.P., 2010. Distributed fiber optic temperature sensors for leakage detection in hydraulic structures. 5th World Conference on Structural Control and Monitoring, 1-9.

Pięta A., Chuchro M., Lupa M., Piórkowski A. \& Leśniak A., 2014. A Model of a System for Stream Data Storage and Analysis Dedicated to Sensor Networks of Embankment Monitoring. Computer Information Systems and Industrial Management, 8838, 514-525.
Piórkowski A. \& Leśniak A., 2014. Możliwości zastosowania strumieniowych baz danych $w$ realizacji system monitorującego stan obwałowań przeciwpowodziowych. Studia Informatica, 35, 2, 297-310.

Stanisz J., Borecka A., Leśniak A. \& Zieliński K., 2014. Wybrane systemy monitorujące obwałowania przeciwpowodziowe. Przeglad Geologiczny, 62, 699-703.

Zhu P., Zeng H., Jiang G. \& Zhou Y., 2009. A novel sensor for monitoring settlement. IX IMEKO World Congress Fundamental and Applied Metrology, 2303-2306. 